\title{
A Study via Interviews of the Chinese Bouyei College Learners' EFL Classroom Anxiety Coping Strategies
}

\author{
Jianhua Wei \\ The School of Foreign Languages, Guangdong Institute of Petrochemical Industry, China
}

\begin{abstract}
The present study aims to investigate EFL classroom anxiety coping strategies employed by the Chinese Bouyei college students through semi-structured individual interviews of 25 Chinese Bouyei college students from five colleges located in the southern and southwestern areas of Guizhou Province, China. The findings demonstrate five categories of the participants' reported EFL classroom anxiety coping strategies, i.e., preparation, help/peer seeking, relaxation, resignation, and positive thinking, which were mostly supportive to the results of the rotated component matrix of factor analysis for the FLCACSQ conducted in the researchers' previous study. In addition, implications were made on the research findings.
\end{abstract}

Index Terms - Chinese, Bouyei, college learners, EFL, anxiety coping strategies, indications

\section{INTRODUCTION}

Anxiety is an unpleasant emotional state or condition which is characterized by subjective feelings of tension, apprehension, and worry, and by activation or arousal of the automatic nervous system (Spielberger, 1972). It is also referred to as a cognitive-affective response characterized by physiological arousal (indicative of sympathetic nervous system activation) and apprehension regarding a potentially negative outcome that the individual perceives as impending (Leary, 1983). In general, anxiety refers to the emotional situation of an individual who is nervous due to the feeling of failure and guilt caused either by the factors which prevent his/her expected goal from a success, or by the obstacles that s/he cannot overcome.

In the foreign language context, anxiety is regarded as a negative factor that attributes to the "affective filter" (Krashen, 1982), because it makes a FL learner less responsive to language input and attempt to convey more concrete messages than those in a non-anxiety-producing setting. Horwitz, Horwitz and Cope (1986) describe FL classroom anxiety as a situation-specific anxiety arising from the uniqueness of the formal learning of a FL, specifically from students' low self-appraisal of their communicative abilities in that language. Horwitz et al. point out that anxiety prevents some people from successfully performing in class, and many people find FL learning, especially in the classroom setting, particularly stressful. Numeral studies show that FL classroom anxiety can bring about a consequence of poor outcomes (Gregersen, 2005), and negatively affect learners' performance and achievement in class (Chen \& Zhang, 2004; Zhao, 2007; Tan, 2009). Some scholars (Spielberge, 1966; Gardner \& MacIntyre, 1993; Horwitz, 2001; MacIntyre \& Gardner, 1991; Young, 1991; Yamashiro \& McLaughlin, 2001) have found out that classroom anxiety exits in FL learners and that higher levels of anxiety tend to indicate lower levels of proficiency in FL learning. Classroom anxiety is indeed a cause of poor English learning in both individuals and situation as an incontestable factor (Horwitz, 2001; Gobel \& Matsuda, 2003; Chen, 2002; Chen \& Zhang, 2004; Liu, 2006; Tan, 2009).

With the development of economical and cultural society, English has become the major compulsory FL course that learners at all levels from primary school to college and university must learn in China. Studies show that classroom anxiety is existent among about one-third or so of the Chinese college students learning English as a foreign language (EFL), and their course grades and interest in English, intentions to continue their study of English, and their CET-4 scores are negatively affected by EFL classroom anxiety (Chen, 2002; Chen \& Zhang, 2004; Liu, 2006; Tan, 2009). Wei's (2012a) quantitative study in use of Horwitz's FLCAS (Foreign Language Classroom Anxiety Scale) (1986:129) reveals that Chinese Bouyei college learners in EFL experienced medium levels of overall classroom anxiety $(M=3.10$, $S D=.68$ ) and communication anxiety, test anxiety, and fear of negative evaluation. However, studies on the anxiety as well as its coping strategies of Chinese college students from minority ethnic groups are still very limited in China, particularly in the remote mountainous areas inhabited by minority ethnic groups. Therefore, this study aims to make a further investigation of the anxiety coping strategies employed by the Chinese Bouyei EFL learners at college who were interviewed for responses to the following research questions (RQ):

RQ1: What are the Chinese Bouyei college students' strategies for coping with their EFL classroom anxiety?

RQ2: What EFL classroom anxiety coping strategies are most frequently reported employed by the Chinese Bouyei college students?

Previous Studies in Relation to Anxiety Coping Strategies 
Coping is of vital importance for alleviating and adapting to environmental pressure and for maintaining both physical and mental health (Wei \& Tang, 1996). Actually, coping refers to the evaluation on the significance of the resources of emergency, control or change of emergent situation, a kind of cognitive activity and behavior to reduce the emotional reaction caused by emergency (Zeidner \& Endler, 1996). However, researchers had different understandings of coping in different periods of time. In 1960s, coping was regarded as a process of adaptation; in the 1970s, a kind of behavior; and in the 1980s, an integration of cognitive activity and behavior (Xiang, 2001). Accordingly, FL classroom anxiety coping styles are of countermeasure that the learners apply to lessening or eliminating anxiety occurring to them in the process of their classroom English learning (Kondo \& Yang, 2004; 2006). It is closely related to a kind of cognitive and behavioral effort which is employed to reduce pressure and injury when FL individuals face embarrassing situations.

As to how to deal with anxiety in the FL context, researchers have devoted a lot to the study of coping styles. It is found that a person often uses more than one coping strategy to cope with an emergent situation, and to cope with the same event, some people even have different coping styles (Chen, 2002). Although a study states that avoidance is the most common strategy used by the students to alleviate their language anxiety (Pappamihiel, 2002), some research indicates that there are at least two types of coping styles, "immature" type and "mature" type, which construct a continuum of "avoidance", "imagination", "self-reproach", "help-seeking", "rationalization", and "problem-solving" (Xiao $\& \mathrm{Xu}, 1996)$. It is argued that the former three belong to the immature coping strategies which may reflect a person's maturity of his/her mental development as a kind of immature type; and the latter three combine the mature coping style because of their positive correlation with problem-solving (Chen, 2002). Marwan (2007) argues that there are four strategies that learners often use in coping with their FL classroom anxiety-preparation, relaxation, positive thinking, and peer seeking (Marwan, 2007). Of these four strategies, peer seeking and relaxation were used by the majority of learners in their attempt to reduce their anxiety followed by the other two strategies, preparation and positive thinking. Whereas, resignation, which refers to "not taking part in class activities" such as "voluntarily answering questions" was not considered by Marwan's participants as a strategy they use to cope with their anxiety in FL classroom (Marwan, 2007). However, low-efficiency-students have been found to actually use resignation as a strategy to cope with their FL anxiety in the classroom (Wu and Zhao, 2006).

It is noteworthy that the Chinese college students learn English as a foreign language (EFL) and they attend CET or TEM in order to obtain relative certificates that help reveal their EFL proficiency for further study and employment. As EFL classroom anxiety is existent among the Chinese college learners, the Chinese college learners must use different coping strategies to reduce or eliminate their anxiety in class (Chen, 2002). Since Chinese and English as well as Chinese and English cultures are quite different, the strategies used for coping with FL anxiety normally may vary a great deal in the classroom. However, a pity is that college learners anxiety coping strategies are most investigated quantitatively in the previous studies. As Wei's (2012b) conducted, for instance, a investigation through a published scale, i.e., the Foreign Language Classroom Anxiety Coping Styles Questionnaire (FLCACSQ) (Chen, 2002:41) found that the Chinese Bouyei college learners claimed to use a medium level of anxiety coping strategies as a whole $(M=2.91, S D=.53)$. And, through factor analysis, the Bouyei informants were found to use five categories of anxiety coping strategies, such as preparation, help/peer seeking, problem solving, resignation, and positive thinking. Nevertheless, Wei has made no analysis of the strategies for cope with EFL classroom anxiety in the voice of the informants in terms of qualitative-oriented study, which embodies the necessity of the present research.

\section{RESEARCH METHODOLOGY}

\section{A. Participants}

The investigation was conducted with 25 1st- and 2nd-year Chinese Bouyei students randomly selected from various classes at each of the following five colleges - the South Guizhou Teachers College for Ethnic Groups, the South Guizhou Vocational College for Ethnic Groups, the South Guizhou Medial Science College for Ethnic Groups, the Xinyi Teachers College for Ethnic Groups, and the Southwest Guizhou Vocational College for Ethnic Groups. The five colleges are located in the south and southwest areas of China's Guizhou Province where a majority of the Chinese Bouyei people are living. Many of the interviewees, however, speak Bouyei language as their mother tongue and come from the countryside.

\section{B. Instrument}

Semi-structured individual interviews with 10 questions (See Appendix 1) translated into Chinese were used to collect data in the present study. As Sandelowski (2002) claims, individual interviews are the most widely-used data collection tool in qualitative research. Price (1991) also asserts that interviews allow the researchers to obtain descriptive information on variables not easily assessed through empirical research, and can provide a way to view phenomena from the point of view of the subjects. Although questionnaires can elicit abundant responses from the participants about their EFL classroom anxiety coping strategies (See Wei, 2002b), interviews are also very helpful in the present study in order to get additional, supplemental information that is valuable from various sources of elicitation. Meanwhile, percentage was also used to identify the frequency of the informants' anxiety coping strategies reported in the interviews. 


\section{Data Collection}

The main areas of the interviews as well as questions for the interviews had been worked out in advance through focus group discussions by the researcher of the present study. After the questions had been refined, the researcher formally collected data from the informants by talking with them face to face in a harmonious atmosphere to collect information as to how they responded to the questions.

\section{Data Analyses}

The individual interviews audio-recorded were listened to and comprehensively transcribed by the researcher who thereafter wrote down the statements of the subjects in relevant sections according to the similarities of the context or situation from which the FL anxiety were resulted. Then data reduction like coding, synthesis, etc. operated repetitiously according to the "open coding" and "axial coding" techniques proposed by Paunch (2005) and Strauss and Corbin's (1998). Percentage of the anxiety coping strategies reported by the interviewees was also used to demonstrate the frequency of related strategies.

\section{RESULTS AND IMPLICATIONS}

To have an overall picture of the interviewees' anxiety coping strategies, the results from the interviews include all possible anxiety coping strategies reported by the 25 Bouyei college students as interviewees with detailed information. Each of the interviewees was labeled with a code according to the time order of being interviewed. For example, ST1 refers to a student who was the first one to be interviewed (See Appendix 2). Through the data analysis of the interviews, the present study has found five categories of anxiety coping strategies under each of which are relative aspects, together with the interviewees' responses. What follows are the inventory of relative coping strategies and the presentation of the key examples of the interviewees' reported strategies, followed by the person-time and percentage of the 25 interviewees who shared the same categories and aspects.

(1) Preparation $(\boldsymbol{P})(18)(72 \%)$

Preparation consists of "working hard for various tests", and "preparation for classroom activities". The two aspects demonstrate that some students spent much time on English study before and after class in order to achieve better in learning English with less anxiety.

- P 1.1: Working hard for various tests (9) $(36 \%)$

Some of the interviewees reported that they spent much time on the preparation of various tests like final exams, CET, and TEM which they were all struggling not to fail, although some of the tests were not so easy to pass. They reported that they were crazily upset when preparing for CET and TEM by doing some more simulation exercises or learning more words by heart in order to overcome test anxiety. For example:

ST12: ...I have never experienced a makeup. However, in order not to fail in any test, I must prepare crazily hard...I know if I fail in a final exam, there is possibility that I might fail another time in the makeup...Then, I will have to pay more for repeated educational service... That will be too bad for me.

ST20: ...I have no confidence to passing TEM. It is very hard. I failed last time although I spent nearly all my spare time on the preparation...I'm nearly crazily upset when preparing for CET and TEM, because they are not easy if you don't spend enough time to prepare so well. It really gets on my nerves.

ST16: ...Not really, if I am well prepared. ...I usually do some make-up exercises after class....However, CET and TEM are too difficult for me and I have no confidence to passing them.

- P 1.2: Preparation for classroom activities (9) (36\%)

Various sorts of preparation for classroom activities were reported employed by some of the interviewees as a coping strategy to their anxiety for the purpose of improving their performances in English class. These interviewees reported that they did not give up learning English by working hard at it although they knew their English was not so satisfactory. For example:

ST11: ...My spoken English is poor and I'm afraid other classmates will laugh at my English pronunciation in discussions... Yes... I think I will first of all improve my pronunciation.

ST14:... To reduce my anxiety in class, I usually choose to volunteer answers and then the teacher usually questions those who seldom volunteer answers. That is a good tactic.

ST4: ...I'm bad at grammar use when expressing my idea both in spoken and written English although I often read grammar books after class.

ST7: ...I try my best to answer the teachers' questions in class in order to improve my ability

(2) Help/peer seeking (HS) (18) (72\%)

Help/Peer Seeking consists of three aspects, "seeking help from peers", "seeking help from the teacher", and "seeking help from the use of Chinese". The three aspects makes clear that some students did not wait but sought assistance in order to go on English learning successfully.

- HS 2.1: Seeking help from peers (9) $(36 \%)$

Some of the interviewees reported that they sought advice from their deskmates, classmates, roommates, and friends. For example:

ST9: ...I exchange feelings with my deskmate when I feel very worried about how to understand a long paragraph 
and so on in English.

ST2: ...My parents know nothing about English learning, so I never communicate with them about my English study...Em ...my classmates can help me with some questions I don't know so well after class.

ST13: ...I feel shy to tell the teacher about my anxiety in English learning, but I can tell my best friends about it and get some opinions from them.

- HS 2.2: Seeking help from the teacher (4) (16\%)

The English teacher was reported by some of the informants as a source of help when they had anxiety in English learning. They asked the teacher to explain the meanings of words, and to pronounce the new words for them as well as provide them with some other advice. For example:

ST1: ...I sometimes inquire the teacher for some advice as to how to pronounce new words as well as how to reduce my worries in English learning. You know, I worry if I can catch up with other classmates.

ST3: ...I feel worried when I cannot pronounce some words correctly. ...My pronunciation needs improvement, I know. However, I will get help from my English teacher either in or after class.

ST15: ...If I meet new words while reading in class, I will ask the teacher for help.

- HS 2.3: Seeking help from the use of Chinese (5) (20\%)

It was reported by some students that they sought help from the use of Chinese instead of their mother tongue when they met difficulty in communication. For example:

ST25: ...In discussions, I'm usually hesitating what to say in English, but sometimes uttering Chinese words instead...

ST1: ... Sometimes, when I cannot express my mind in English, I speak Chinese instead so that my counterpart can easily understand. It's really embarrassing when not knowing how to utter some English words.

ST7: ... I feel awkward while speaking English which I'm not so good at, so Chinese is what I often use in the middle of the pair work and discussions.

(3) Relaxation (RLX) (4) (64\%)

Relaxation consists of three aspects, "turning concentration away from class activities", "taking a deep breath", and "imagining the audience to be less prepared". The three aspects display that some students conducted such tactics that could effectively help them relax in order to perform better in FL class.

- RLX 4.1: Turning concentration away from class activities (7) (28\%)

They also reported that they chose to turn their concentration away from class activities by reading some stories, pictorials, and text books themselves, listening to MP3 music, and even pinching the arm or leg or going out to wash face in order to feel relaxed from class. For example:

ST2: ... When I feel worried about my English learning, I choose to read some stories instead.

ST8: ...I read some pictorials in class if I am nervous, for they are easy to understand.

ST9: ...I look out of the windows far away into the sky. This may help make me better when feeling bad in English class.

ST16: ...I sometimes pinch my arm or leg... and it makes sense as a refreshing method when I feel bad.

- RLX 4.2: Taking a deep breath (6) (24\%)

Taking a deep breath is what some interviewees reported as a tactic of relaxation. They usually took a deep breath while entering the examination room, and when going to the $\mathrm{Bb}$ for presentations or speaking to the whole class on behalf of other group members. For example:

ST1: ... Before I go to the Bb for my presentation, I'm used to taking a deep breath. This really makes me relaxed in English class.

ST3: ...I'd like to take a deep breath when the teacher asks me to go to the Bb to do some writing exercises. I know I may make mistakes.

ST5: ...I shake hands with some of my group members and take a deep breath when going to the Bb as required for a oral report about what we have discussed.

ST10: ...I take a deep breath before a test, although I am not so afraid of test if I am well prepared.

- RLX 4.3: Imagining the audience to be less prepared (3) (12\%)

Some of the interviewees reported that they usually imagined other classmates in class to be the audience who might be less prepared while they were doing some presentations to the whole class as required. They said:

STI15: ... I believe that other classmates may be not so well prepared with this question and might not know how to express their minds as well as I was doing. This makes me relaxed a lot and become less worried.

ST13: ...It really happens, I believe, that other peers are not as well-prepared as you are, but you are too much nervous about whether you would do as well as others. In this case, I choose to pretend that I am much better at knowing about things than my peers. This makes me a bit relaxed.

ST8: ...However hard I try to overcome my anxiety in class, my anxiety seems never to disappear. So I choose to force myself to think that other people may be "stupid" and I am smart enough in many aspects.

(4) Resignation (RSN) (12) (48\%)

Resignation consists of "avoiding participation in classroom activities", and "staying away from school". The two aspects illustrate that some students did not leave English class but chose to do something else like sleep in class, chat 
on the cell-phone, and refuse to take part in any classroom activities, and some stayed away from class by asking for leave, playing truant, and leaving early during class.

- RSN 5.1 Avoiding participation in classroom activities (8) $(32 \%)$

Some of the students reported that they do not leave English class but choose to do something else like sleep in class, chat on the cell-phone, and refuse to take part in any classroom activities. For example:

ST1: ...Well, I'm not sure what I can learn ....so I'm not so willing to go to English class for the reason that it might be a waste of time... because what I can do is to sleep in English class.

ST6: ...I sometimes turn to chat on my cell-phone if the English teacher's class is quite boring... This happens many times.

ST16: ...I usually say, "Sorry, I don't know", while blushing with a shame. Then the teacher would change to ask others.

ST7: ...I never give up learning English, but sometimes keep silence in class to avoid getting involved in discussions when I am not so well prepared for some other reason.

- RSN 5.2 Staying away from class (4) $(16 \%)$

In a very casual, and harmonious atmosphere, a few of the interviewees honestly reported that they even chose to stay away from class by asking for leave, playing truant, and leaving early during class. For example:

ST12: ...My English is not bad in class. However, I occasionally resign some single class if I forget to do homework and not able to hand it in the next day. I know it is not good to tell a lie though, I sometimes pretend that I am ill. What a shame...

ST25: ... The English teacher does not encourage us with efforts...I feel bored and sometimes stay in the library instead reading English books myself.

ST3: ...I know about the discipline of the school although I escape from class every now and then. ...Um...some of my close friends sometimes help find some excuse for my absence.

(5)Positive thinking (PT) (10) (40\%)

Positive thinking consists of two aspects, "planning to work harder at English learning", and "conducting self-encouragement". The two aspects indicate that some students decided to take some measures to improve their FL learning, as well as not to lose hope in FL learning.

- PT 3.1: Planning to work harder at English learning (3) (12\%)

Some of the students reported that they would work harder at English learning although they had difficulty in it. For example:

ST1: ... English is not my strength although I'm interested in it. I will turn to exert myself to fulfill my wish in other fields in order to achieve better results. However, I will not totally give up English learning, especially English speaking.

ST9: ...Honestly speaking, how I yearn the years when my English was good at junior high school and received some awards from the English teacher. I hope I can be as confident as before if I do not give up and work harder from now on.

ST15: ...I know my English is poor, but I believe if I work harder, there is possibility that I can make progress and learn something needed for my future.

- PT 3.2: Conducting self-encouragement (7) (28\%)

Some of the interviewees reported that they usually encourage themselves by being determined not to give up learning English as well as struggling for passing CET although their progress is low. They also reported that they tried to reduce their anxiety by saying something to themselves when encountering anxiety and believed they would be okay. For example:

ST6: ...I think I will not give up English learning although my progress is not obvious.

ST7: ...I would compare the present anxiety with the past that made me more worried, and tell myself that I have made greater progress at present.

ST11: ... I usually say to me, "Your difficulty is merely temporary. Go ahead, ...."

ST16: ...Yes, I do. I say with firm belief to myself, "I will be okay later on. Just wait and see."

The above findings reveal that preparation (18) (72\%) and help/peer seeking (18) (72\%) seem to be the most frequently reported categories of anxiety coping strategies followed by relaxation (4) (64\%) that the interviewees employed. It is noteworthy that the former two are consistent with the most commonly employed coping strategies found the rotated component matrix of factor analysis for the FLCACSQ conducted in the researchers' previous study (Wei, 2012b: 31-43). However, the other two anxiety coping strategies were supportively associated with Wei's quantitative study in use of the closed-ended questionnaire, whereas the strategy problem solving was little reported by the interviewees and therefore was not considered a strategy the informants commonly employed.

\section{CONCLUSION}

Based on the analysis of the data collected from the semi-structured individual interviews, it seems that the Chinese Bouyei college students mainly employed five categories of strategies (preparation, help/peer seeking, relaxation, resignation, and positive thinking) for coping with their classroom anxiety in EFL. The research manifests their solutions to lessen their FL classroom anxiety as doing preparation for class, seeking help from peers, the English 
teacher and others, employing tactics that could effectively help relax in order to perform better in EFL class, doing something else to temporary solve the problems, avoiding participating in classroom activities, and conducting positive thinking. Interestingly, the results in terms of frequency of the reported coping strategies mostly support the researcher's previous quantitative study, showing that the Chinese Bouyei college students' first two most commonly employed coping strategies are related to preparation, and help/peer seeking, although the third most commonly employed was not positive solving but relaxation that differentiates Wei's previous findings. Nevertheless, this also indicates that their coping styles are also of "mature" type (Wei, 2012b), which demonstrates the necessity and stringency of the teacher's effort to act as a facilitator in EFL classroom by developing a harmonious relationship with the learners and showing much concern about college EFL learners with different characteristics and various personalities.

\section{APPENDIX 1 INDIVIDUAL INTERVIEW QUESTIONS FOR COLLEGE EFL LEARNERS}

Q1: Do you feel worried and depressed about your English study in class? Do you have the feeling of not going to English class? Why?

Q2: Are you worried when listening to the tape, the English teacher, or the native speaker in class? Can you tell me the reason? How do you cope with such worries?

Q3: Do you feel pressure when required to read some English materials in class? Why? What do you do to deal with such pressure?

Q4: How do you feel when you know you have to perform a task of output like speaking or writing in your English classroom? Why? What do you usually do in face of such situation?

Q5: What are the distinctive differences between the acquisition environments of Bouyei language, Chinese language, and English that cause language anxiety for an EFL learner? Why?

Q6: What do you think are the main factors contributing to your nervousness or anxiety in English class? (language competence, personality traits, classroom settings, cultural differences, language test, social status and self-identity, or anything else)

Q7: Whom do you often go to for advice or to exchange feelings with about your worries in English learning?

Q8: What more do you usually do to reduce stress or anxiety in English class?

Q9: What do you think the English teacher could do to help reduce your anxiety in class?

Q10: What else would you like to suggest for reducing foreign language anxiety in the college learners?

P.S. The Chinese Version of the Individual Questions for College EFL Learners: 大学生英语学习焦虑及其应对 策略个别访谈问题

1. 在英语课堂学习上, 你感到焦虑和沮丧吗? 为什么?

2. 在听磁带, 听英语教师和外教讲课时,你感到焦虑吗? 为什么? 你是如何应对的?

3. 当老师让你在课堂上阅读英语材料时，你有压力吗? 原因是什么? 你是任何处理的?

4. 老师让你在课堂上进行英语口头或笔头表达时, 你有什么样的感受? 为什么? 你又是怎样应对的?

5. 你认为在学习布依语、汉语和英语之间, 有些什么明显的差别? 哪一种学习更容易造成更大的学习焦虑? 为什么?

6. 你觉得造成英语课堂学习焦虑的主要因素是什么? (语言能力, 个性差异, 课堂环境, 文化差异, 语言测试, 社 会地位和自我认证，等等）

7. 你通常和谁进行交流，以便听取他们关于如何克服英语学习焦虑情绪的建设性意见?

8. 对于任何减少英语学习的压力和焦虑, 你通常还采取哪些应对办法?

9. 你觉得英语教师该怎样做, 才能帮助你减少课堂学习焦虑?

10. 对存在英语课堂学习焦虑的同学, 你还有哪些可行的建议?

\section{APPENDIX 2 A SAMPLE INTERVIEW SCRIPT (THE ENGLISH VERSION)}

Interviewer: Wei Jianhua

Interviewee: ST21

Date: September 27, 2011

Time: 3:10 p.m.

Place: South Guizhou Teachers College for Ethnic Groups

Me: Good afternoon.

ST16: Good afternoon.

Me: Please take your seat.

ST16: Thank you.

Me: Could I know you name, please?

ST16: Yes, my name is ....

Me: My name is Wei Jianhua. Thank you for your coming to the interview. 
ST16: It's my pleasure.

Me: When did you start learning English?

ST16: En...a temporary teacher, who knew a little English, taught us some when we were at primary school. Actually, we formally started learning English from the first year at junior middle school.

Me: Do you feel worried and depressed about your English study in class at college?

ST16: Um...yes, I feel nervous when I answer questions in class.

Me: Do you even tremble?

ST16: (Laughs) Sometimes... I tremble sometimes.

Me: Why?

ST16: I feel worried when I don't understand what the teacher says; but if I understand, I am not so worried.

Me: That means if you understand, you can also be worried, but not that much?

ST16: Yes.

Me: Do you have the feeling of not going to English class?

ST16: Sometimes, especially, when I first came to college.

Me: Can you tell me the reason?

ST16: I am a bit timid and I don't know about grammar...my grammar is poor, and... my vocabulary is inadequate. I'm not good at grammatical structure...about the subject, the predicate, object, etc... and how to connect words in proper order. I feel bad when seeing others speak better than I do.

Me: How can it be like that?

ST16: When we were at senior higher school, the English teacher merely read the text to us and told us the meanings of the sentences... What's more, we were also lazy and didn't explore effective learning approaches about how to study English well...These might be the reason.

Me: Are you in the same situation at college now?

ST16: It's a bit better now, but terrible during the first term. I felt bored and I didn't find it interesting...maybe because of the way the teacher taught us. I remember we met an English teacher from South Korea at junior high school, and we were all very much interested in her lessons with a lot of fun... She taught us in a very interesting way.

Me: Are you still depressed in English learning as before?

ST16: Not so much and I am studying harder now.

Me: What brings you to a change?

ST16: We have had some new English teachers since last term whose lessons were more interesting. What's more, I have to pass the terminal exams of a few English courses like Listening, English Speaking, General English, and English Writing. In addition, I have to prepare for my CET and TEM. I cannot stay where I was.

Me: You have already a lot to do. Why must you attend CET and TEM?

ST16: They are important for job-seeking in future, I am told. I'm puzzled for that...You know, my English is nor satisfactory.

Me: Are you worried when listening to the tape, the English teacher, or the native speaker in class?

ST16: However, I find it even harder to understand the Chinese English teachers because they sometimes speak too much and too fast, even faster than native speakers with no care for our understanding. The fact may be that native speakers care more for our comprehensive competence than the Chinese ones.

Me: How do you cope with such worries?

ST16: Um...I usually do some make-up exercises after class.

Me: What about in class?

ST16: I have to endure the fact that I am weak in such activities.

Me: Do you say something to yourself in order not to worry so much?

ST16: ...Yes, I do. I say with firm belief to myself, "I will be okay later on. Just wait and see."

Me: Do you feel pressure when required to read some English materials in class?

ST16: Not really ... if I have no new words... and I can ask the teacher for help if I meet words I don't know.

Me: How do you feel when you know you have to perform a task of output like speaking or writing in your English classroom?

ST16: Well, I'm very nervous

Me: Why?

ST16: Because my spoken English is very poor. And I fear that others would laugh at my mistakes when answering the teacher's questions orally.

Me: What do you usually do in face of such situation?

ST16: (Laughs shyly) I usually say, "Sorry, I don't know", while blushing with a shame. Then the teacher would change to ask others.

Me: Do you have anxiety in writing in class?

ST16: Yes, when I don't know how to express my mind in English...Instead, I choose to write in the style of Chinese regardless of English grammar... or use some Chinese characters in the sentence.

Me: Another question: What are the differences between the acquisition environments of Bouyei language, 
Chinese language, and English that cause language anxiety for an EFL learner? Why?

ST16: For me, we are Chinese and so feel bigger anxiety in learning English than in learning Chinese. I speak Bouyei as well as Chinese naturally since I started to learn Chinese in the first year at primary school...; but for English, we learned it very late and had no other people speaking English with us around ... and their sentence structures and sounds are quite different... hard to learn it well, you can imagine.

Me: What do you think are the main factors contributing to your nervousness or anxiety in English class? (The researcher slowly says out one by one the following factors as choices given: language competence, personality traits, classroom procedure, cultural differences, language test, social status and self-identity, etc.)

ST16: I think they are mainly language competence, personality traits, cultural differences, and language tests.

Me: Are you an introvert or an extrovert? Why do you think personality traits can contribute to anxiety?

ST16: I was an introvert before, but I am becoming an extrovert now. I think extroverts are usually more open-minded and like to talk with people, so they can learn English better and faster.

Me: Are you confident to your English study?

ST16: Yes. I believe I can catch up with others.

Me: Do you think self-esteem can help you with bigger effort to reduce your anxiety?

ST16: I think so. Since I have a strong esteem, I don't want to be looked down upon by others, so I will work harder than before so that I can participate in all classroom activities. With my English improved, I believe I will have less anxiety.

Me: Why don't you regard social status and self-identity as a factor that causes English learning anxiety in class? For example, you may have a sense of inferiority because you are a minority person from the countryside... and by the way, I am also a Bouyei who grew up with such a feeling in the countryside.

ST16: Um... I come from the countryside as a minority student, but there are many other minority students in class. Hans are not so many in my class. However, my cousin has the problem in Shanghai University, where there are less minority students. Actually, her problem is not that serious and she even feels a bit "superior" for her being able to speak not only Chinese, but also Bouyei language and some people even feel curious about the minority students. In this case, I have not such feeling.

ST16: What about if you feel inferior and are in fear of being laughed by those classmates whose English you think is better than yours?

ST16: In this case, I really feel depressed while others seem unwillingly to speak with me in discussions because my spoken English is poor.

Me: That's very interesting. Are you afraid of tests very much?

ST16: Not really, if I am well prepared. However, CET and TEM are too difficult for me and I have no confidence to passing them.

Me: What more you think are responsible for anxiety?

ST16: The teacher's teaching approaches, I think. You see, we felt it interesting to learn English with that English teacher from Korea at junior high school. Some college English teachers are serious and their teachings not so interesting to us.

Me: Whom do you often go to for advice or to exchange feelings with about your worries in English learning?

ST16: I often communicate with my classmates and get help from them.

Me: Do you communicate with your parents about your anxiety?

ST16: No. They know nothing about English study.

Me: What about asking the teacher for some advice?

ST16: Yes. I sometimes do... it just depends. However, some teachers seem busy.

Me: You don't fear that the teacher or your classmates may then have a negative impression on yourself?

ST16: I do. I am afraid the teacher and my classmates would lay a special eye on me.

Me: What more do you usually do to reduce stress or anxiety in English class?

ST16: I sometimes pinch my arm or leg....and it makes sense as a refreshing method when I feel bad.

Me: Really?

ST16: Um yes.

Me: Interesting. Uh... What do you think the English teacher should do to help reduce your anxiety in class?

ST16: Give us more chances to do pair work in class, not only to listen to the dialogue in the tape or merely to speak to the whole class.

Me: Good. Don't you want the teacher to ask you to do exercises on the blackboard or to answer questions in front of the blackboard?

ST16: Um...I really want the teacher to do that, but I sometime am not so aware of what to do.

Me: I see. Uh...What else would you like to suggest for reducing foreign language anxiety in the college learners?

ST16: Um...I think... the teacher should carry out new...innovative classroom procedures... so that the English students can learn English more efficiently...um... with less anxiety... but... more motivation stimulated.

Me: Good suggestion...Anything else? 
ST16: The teachers speak too much in class...They speak, speak, and speak...and we should be given time to speak too. We need time to practice and then get improved. Furthermore, the students' interest in English is the foremost, or they will loose heart.

Me: Thank you so much for your useful and valuable information about classroom anxiety and relative coping styles.

\section{REFERENCES}

[1] Chen, H. (2002). College students' English learning anxiety and their coping styles. M.A. dissertation, Southwest Normal University, http://www.cnki.net/kcms/detail/Detail.aspx?dbname=CDMDTOTAL\&filename=2002113517.nh\&filetitle=大学生 英语学习

[2] Chen, X.L, \& Zhang, M. (2004). Foreign language anxiety and students' achievements of college-English. Journal of Chongqing University (Social Sciences Edition), 10 (5), 114-117.

[3] Gardner, R. C., \& MacIntyre, P. D. (1993). On the measurement of affective variables in second language learning. Language Learning, 43, 157-194.

[4] Gardner, R. C., \& MacIntyre, P. D. (1993). On the measurement of affective variables in second language learning. Language Learning, 43, 157-194.

[5] Gobel, P., \& Matsuda, S. (2003). Anxiety and predictors of performance in the foreign language classroom, Science Direct Journal, 32 (1), 21-36.

[6] Gregersen, T. S. (2005). Nonverbal cues: Clues to the detection of foreign language anxiety. Foreign Language Annals, 38 (3), $388-400$.

[7] Horwitz, E. K. (Ed.) (2001). Language anxiety and achievement. Annual Review of Applied Linguistics, 21, 112-126.

[8] Kondo, D. S. (1997). Strategies for coping with test anxiety. Anxiety, Stress and Coping, 10, 203-215.

[9] Krashen, S. D. (1982). Principles and Practice in Second Language Learning. New York: Pengamon.

[10] Leary, M. (1986). Understanding Social Anxiety: Social Personality, and Clinical Perspective. Beverly Hills: Sage Publications.

[11] Liu, M. (2006). Anxiety in Chinese EFL students at different proficiency levels. System, 34(3): 301-316.

[12] MacIntyre, P. D., \& Gardner, R. C. (1991). Investigating language class anxiety using the focused essay technique. The Modern Language Journal, 75 (3), 296-313.

[13] Marwan, A. (2007). Investigating students' foreign language anxiety. Malaysian Journal of ELT Research, 3, 37-55.

[14] Pappamihiel, N. E. (2002). English as a second language students and English language anxiety: Issues in the mainstream classroom. Research in the Teaching of English, 36(3), 327-355.

[15] Paunch, K. (2005). Introduction to social research: Quantitative and qualitative approaches (2 $2^{\text {nd }}$ ed.). London: Sage.

[16] Price, M. L. (1991). The Subjective Experience of Foreign Language Anxiety: Interviews with High Anxious Students, in Horwitz, E.K., \& Young, D. J. (eds.) Language Anxiety: From Theory and Research to Classroom Implications. Englewood Cliffs, NJ: Prentice Hall.

[17] Sandelowski, M. (2002). Re-embodying qualitative inquiry. Qualitative Health Research, 12, 104-115.

[18] Spielberger, D. (1966). Anxiety and Behavior, New York: Academic Press.

[19] Spielberger, D. (1972). Anxiety: Current Trends in Theory and Research, New York: Academic Press.

[20] Strauss, A., \& Corbin, J. (1998). Basic of Qualitative Research: Techniques and Procedures for Developing Ground Theory (2 ${ }^{\text {nd }}$ ed.). Thousand Oaks, California: SAGE.

[21] Tan, Y. (2009). The relationship between anxiety and college students' achievements: A survey of non-English majors. Journal of Suzhou University of Science and Technology (Social Sciences), 26(2), 142-144.

[22] Wei, J.H. (2002a).The Chinese Bouyei college students' classroom anxiety in foreign language learning: A survey study. International Journal of English Linguistics, 2 (2): 75-90.

[23] Wei, J.H. (2002b). The Chinese Bouyei College Students' Strategies for Coping with Classroom Anxiety in Foreign Language Learning: A Survey Study. World Journal of English Language, 2 (1):31-43.

[24] Wei, Y.H \& Tang, S.Q. (1996). The Initially Revised Coping Styles Questionnaire. The Journal of Psychology, 4, 378-387.

[25] Xiang, S. J. (2001). An experimental study of junior high school students' self-control training in coping with frustrations. Unpublished M.A. dissertation of the Psychology Department of Southwest China Teachers University, Chongqing, China.

[26] Xiao, J. H \& Xu, X. F. (1996). The validity and reliability of the Coping Styles Questionnaire. The Journal of Chinese Psychological Sanitation, 4, 164-168.

[27] Yamashiro, A.D., \& McLaughlin, J. (2001). Relationships among attitudes, motivation, anxiety, and English language proficiency in Japanese college students. In: P. Robinson, M. Sawyer \& S. Ross (Eds.), Second language acquisition research in Japan: JALT Applied Materials Series, Vol. 4 (pp. 19-33). Tokyo: Japan Association of Language Teachers Press.

[28] Young, D. J. (1991). Creating a low-anxiety classroom environment: What does language anxiety research suggest? The Modern Language Journal, 75(4), 426-439.

[29] Zeidner, M. \& Endler, N. (1996). Handbook of Coping. New York: John Wiley \& Sons, Inc.

[30] Zhao, N. (2007). A study of high school students' English learning anxiety. The Asian EFL Journal, 9(3), 22-34.

Jianhua Wei was born in Sandu, China in 1964. He received his M.A. degree in English language studies from the Suranaree University of Technology, Thailand in 2012.

$\mathrm{He}$ is currently a professor in the School of Foreign Languages, the Guangdong Institute of Petrochemical Industry, Maoming, China. His research interests include SLA, teaching methodology, and translation theory and practice.

Prof. Wei is a member of the Translators Association of China. 